\title{
Yoğun bakım ünitesinde yatan hastaların klinik örneklerinden izole edilen Candida türlerinin dağılımı ve antifungal duyarlııkları
}

\author{
Ünsal Savcl ${ }^{1 *}$ (D), Mustafa Şahin ${ }^{2}$ (D), Havva Hande Keser Şahin ${ }^{3}$ \\ ${ }^{1}$ Hitit Üniversitesi Erol Olçok Eğitim ve Araştırma Hastanesi, Tıbbi Mikrobiyoloji Laboratuvarı, Çorum, Türkiye \\ ${ }^{2}$ Hitit Üniversitesi Erol Olçok Eğitim ve Araştırma Hastanesi, Tıbbi Biyokimya Laboratuvarı, Çorum, Türkiye \\ ${ }^{3}$ Hitit Üniversitesi Erol Olçok Eğitim ve Araştırma Hastanesi, Patoloji Kliniği, Çorum, Türkiye \\ * Sorumlu Yazar: Ünsal Savcı E-posta: unsalsavci@gmail.com ORCID: 0000-0003-2319-8171 \\ Gönderim: 12 Kasım 2018 Kabul: 14 Aralık 2018
}

\section{Sayın Editör,}

Yoğun bakım ünitesinde yatan hastaların klinik örneklerinden izole edilen Candida türlerinin dağılımı ve antifungal duyarlılıklarını belirlemeyi amaçladıkları Altın ve arkadaşlarının yakın zamanda yayınlanmış olan makalesini büyük bir ilgi ile okuduk. Bu çalışmada yoğun bakım ünitesinde yatan hastalarda Candida türlerinin sıklığının ve antifungal duyarlılıklarının saptanması hem antifungal tedavinin planlanması hem de etkene spesifik antifungal tedavinin belirlenmesi açısından gerekli olduğu sonucuna varmışlardır.

Ancak, bu çalışma hakkında vurgulanması gereken bazı önemli noktalar olduğunu düşünüyoruz [1].

İlk olarak, mikroorganizma dağılımlarının ve antifungal duyarlılıklarının araştırıldığı çalışmalarda izole edilen suş sayısının yeterli olması, örnek dağılımlarının mümkün olduğu kadar homojen olması araştırmanın sunduğu verilerin güvenilirliğini artıracaktır. Çalışmada örnek sayıları retrospektif bir çalışmaya göre daha fazla olmalıydı. Ayrıca örnek büyüklüğünü arttırmak suretiyle istatistikî anlamlılığı da artırmak mümkün olacaktır [2].

Yoğun bakım ünitelerindeki enfeksiyonların \%80'inden fazlasını ventilatör ilişkili pnömoni, kateterle ilişkili kan dolaşımı enfeksiyonları ve üriner enfeksiyonlar oluşturmaktadır [3]. Bu çalışmada idrar örnekleri tüm örneklerin yaklaşık \%90'lık kısmını oluşturmaktadır. Bu durum mikroorganizma dağılımlarını ve antibiyotik duyarlılıklarını etkileyebilir.

İkincisi, izole edilen Candida türlerinin kontaminasyon veya flora elemanları mı yoksa patojen etken mi olduğunun ve enfeksiyon ile ilişkisinin belirlenmesi gereklidir. Ayrıca çalışmada idrar kültürlerinde Candida üreyen izolatların tamamında idrar sondası mevcuttur.

Semptomatik üriner sistem enfeksiyonu; idrar kültüründe Candida türünün izole edilmesi, ateş $>38^{\circ} \mathrm{C}$, pollaküri, dizüri ve suprapubik hassasiyet gibi semptom ve bulgulardan en az birinin mevcudiyeti olarak tanımlanır. Üriner kateter kolonizasyonu; idrar kateteri olan hastanın, idrar kültüründe Candida türünün izole edilmesi ve yukarıdaki semptom ve bulgulardan hiçbirinin olmaması üriner kateter kolonizasyonu olarak tanımlanır [4].

Sonuç olarak, bu tür çalışmalarda örnek sayısının yeterli olması, tüm klinik örnekleri kapsaması ve izole edilen mikroorganizmaların enfeksiyon etkeni olup olmadığının saptanması sonuçların daha güvenilir olmasını sağlayacaktır.

\section{Saygılarımızla.}




\section{KAYNAKLAR}

1. Altın N, Cesur S, Toros GY, Koldaş K, Solgun G, Şencan I. Yoğun bakım ünitesinde yatan hastaların klinik örneklerinden izole edilen Candida türlerinin dağılımı ve antifungal duyarlılıkları. Ortadoğu Tıp Derg 2018; 10: 130-4.

2. Akgöz S, Ercan İ, Kan İ. Meta-analizi. Uludağ Üniversitesi Tıp Fak Derg. 2004; 30: 107-12.
3. Palabıyıkoğlu í. Yoğun bakım ünitesi enfeksiyonlarında patogenez. Turkiye Klinikleri J Int Med Sci 2006; 2: 11-22.

4. Erdem F, Tuncer Ertem G, Oral B, Karakoç E, Demiröz AP, Tülek N. Candida türlerine bağlı nozokomiyal enfeksiyonların epidemiyolojik ve mikrobiyolojik açıdan değerlendirilmesi. Mikrobiyol Bul 2012; 46: 637-48. 